\section{Physical Impedance Retards Top Growth of Tomato Transplants}

\author{
Cyrus Samimy ${ }^{1}$ \\ New York State Agricultural Experiment Station, Department of Horticultural \\ Sciences, Cornell University, Geneva, NY 14456
}

Additional index words. Lycopersicon esculentum, mechanical stress, growth control, plug transplants

Abstract. Two-week-old 'Ohio 8245' tomato (Lycopersicon esculentum Mill.) seedlings were subjected to physical impedance by placing a sheet of Plexiglas on the shoots for 15 hours a night for 12 consecutive nights. This treatment reduced stem length by $21 \%$ and increased stem diameter by $20 \%$ compared to nontreated plants. Stems of treated seedlings were considered sturdier than those of nontreated seedlings since the treated seedlings remained erect for 28 to 33 days after impedance ended and the stems of control seedlings did not. Forty-four days after impedance ended, stems of treated plants were $18 \%$ shorter and 9\% thicker than those of nontreated plants. The results showed that tomato seedlings subjected to impedance developed growth characteristics that are desirable in transplants.

The use of greenhouse-grown, plug transplants to establish processing tomatoes in the field is replacing the use of field-grown transplants. The close spacing of plants in plug trays (200 to 400 cells/tray) can cause etiolation and excessively tall, low-quality transplants with thin stems. Thus, controlling seedling height in the greenhouse has become a major challenge to plug-transplant producers. Breaking tomato transplant stems during shipping or exposure to post-transplant winds would be less likely in short, sturdy seedlings. Applying the growth retardant butanedioic acid mono (2,2-dimethylhydrazide) (daminozide, B-nine) no longer is permitted to control the growth of vegetable transplants. Therefore, research efforts have been directed toward studying the feasibility and effectiveness of nonchemical methods for restricting transplant stem elongation.

Nonchemical height-control methods for seedlings that werereviewed by Latimer( 1991)

\footnotetext{
Received for publication 20 Nov. 1992. Accepted for publication 22 Apr. 1993. This research was conducted at the New York State Agricultural Experiment Station, Geneva, NY. I thank H.C. Price, R.W. Robinson, and the reviewers for critical readings of earlier drafts of this manuscript. Use of trade names does not imply endorsement of the products named nor criticism of similar ones not named. The cost of publishing this paper was defrayed in part by the payment of page charges. Under postal regulations, this paper therefore must be hereby marked advertisement solely to indicate this fact.

${ }^{1}$ Research Associate.
}

Shaking tomato seedlings grown in a greenhouse retarded axial and lateral stem growth and strengthened the tissue (Heuchert and Mitchell, 1983; Heuchert et al., 1983; Mitchell et al., 1975). All three methods mentioned (brushing, vibrating, and shaking) reduced leaf growth. In the present study, I examined the effects of restricting seedling height by placing an obstacle on top of the shoots.

'Ohio 8245 ' tomato seeds were sown on 21 July 1992 and 23 Dec. 1992 in 200-cell polystyrene plug trays $(67.2 \times 34.2 \times 7.5 \mathrm{~cm})$ with $25-\mathrm{cm}^{3}$ inverted-pyramid cells. $(2.7 \times 2.7 \times 7.5$ $\mathrm{cm}$ deep) filled with Cornell growth medium (Boodley and Sheldrake, 1977). The trays were maintained in a greenhouse (average $38 \mathrm{C}$ day maximum and $16 \mathrm{C}$ night minimum in both seasons). Plants were maintained under natural light in summer, but, in winter, natural light was supplemented by two $185-\mathrm{W}$ coolwhite fluorescent lamps placed $70 \mathrm{~cm}$ above the plant tops to provide a 14 -h photoperiod. Two weeks after seeding, when the first true leaves were expanding, a sheet $(37.0 \times 70.0 \times$ $0.5 \mathrm{~cm}, 1.8 \mathrm{~kg}$ ) of clear acrylic Plexiglas (Rohm and Haas Co., Philadelphia), supported on two sides, was placed over the seedlings causing $70 \%$ to $90 \%$ of the seedling stems to deviate 35 " to 50 " from vertical (Fig. 1). If distributed equally, the weight on each seedling would have been $9 \mathrm{~g}$. The Plexiglas was applied at $1700 \mathrm{HR}$ and removed at $0800 \mathrm{HR}$ for 12 consecutive nights. After 10 nights, when seedlings were able to withstand the weight of the Plexiglas, the supports were removed.

Each treatment group (control or those receiving impedance), consisting of 200 plants growing in a plug tray, was replicated twice over time in a completely randomized block design. Stem length, stem diameter $1 \mathrm{~cm}$ above the cotyledonaty node, and leaf lamina dry weight of 10 representative 29-day-old plants

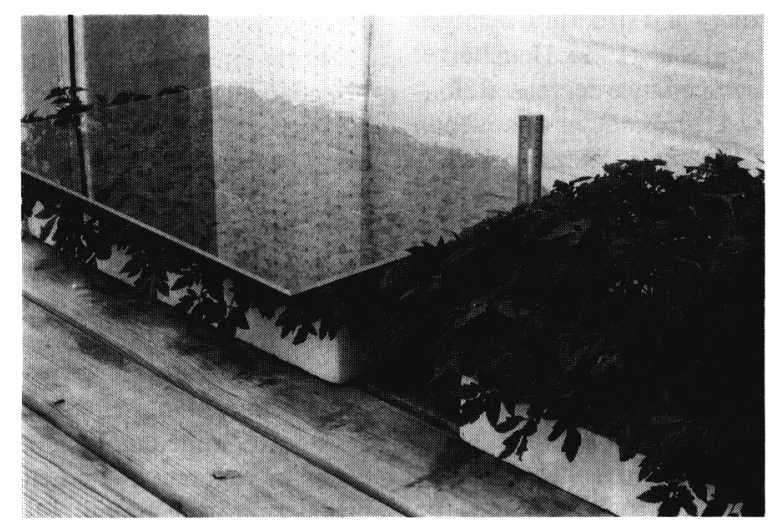

Fig. 1. Tomato seedlings subjected to physical impedance by a sheet of Plexiglas supported on two sides. 
Table 1. Growth characteristics of 29-day-old tomato seedlings after 3 days after 12 nights of being subjected to physical impedance.

\begin{tabular}{|c|c|c|c|}
\hline \multirow[b]{2}{*}{ Treatment } & \multicolumn{2}{|c|}{ Stem } & \multirow{2}{*}{$\begin{array}{l}\text { Leaf lamin } \\
\text { dry wt } \\
\text { (mg/plant) }\end{array}$} \\
\hline & $\begin{array}{c}\text { Length } \\
(\mathrm{cm})\end{array}$ & $\begin{array}{l}\text { Diam } \\
(\mathrm{mm})\end{array}$ & \\
\hline Control & 14.6 & 3.0 & 81 \\
\hline Impedance & 11.6 & 3.6 & 72 \\
\hline$F$ test & $* * *$ & $* * *$ & NS \\
\hline
\end{tabular}

from each treatment group were determined 3 days after impedance ended.

An additional five plants from each treatment group were transplanted into $1870-\mathrm{cm}^{3}$ (17-cm-diameter) clay pots filled with Cornell growth medium 29 days after seeding. These plants were maintained in a greenhouse under the same light and temperature conditions describedearlier. Fertilizer (20N-8.8P-16.6K) was applied at $600 \mathrm{mg} \mathrm{N} /$ liter to the growth medium five times $(13,20,38,52$, and 62 days) after seeding. Daily irrigation using a sprayer at low pressure ensured minimum disruption of seedling stature and adequate, uniform wetting of the growth medium. When these plants were 70 days old (44 days after impedance ended), their stems were cut at the growth medium's surface and the following growth characteristics were determined: stem length, stem diameter $25 \mathrm{~cm}$ above the growth medium's surface, leaf laminadry weight, and fruit count and fresh weight (all immature). A vernier caliper was used to measure stem diameter. The dry weights of $1-\mathrm{cm}^{2}$ laminar disks collected from the top four leaves of each plant were used to calculate specific leaf weights. Leaf area per plant was determined by dividing the total leaf lamina dry weight by specific leaf weight. Dry weights were determined after 3 days at $80 \mathrm{C}$.

Impedance reduced stem length of 29-dayold tomato seedlings by $21 \%$ and increased stem diameter by $20 \%$, relatiye to control plants (Table 1, Fig. 2). Leaf dry weights were not affected by impedance. The previously impeded plants remained erect for 28 to 33 days after impedance ended, whereas the nontreated plants collapsed under their own weight a few days after being transplanted (Fig. 3). The impeded plants' resistance to stem deformation could be attributed to increased stem thickness and structural changes in the tissues (Goeschl et al., 1966; Heuchert et al., 1983). Physical impedance decreased elongation and increased the diameter of soybean (Glycine max L.) hypocotyls (Samimy, 1980), pea (Pisum sativum L.) epicotyls (Goeschl et al., 1966), and Lilium longiflorum Thunb. stems (Hiraki and Ota, 1975) and enhanced ethylene synthesis. Moreover, the effects of impedance were duplicated by applying ethylene (Goeschl et al., 1966; Hiraki and Ota, 1975; Samimy, 1980). The stunted growth and enlarged diameter of the 29-day-old tomato seedling stems subjected to impedance in this study indicate that enhanced ethylene production may be responsible for these morphological features. Other mechanical stresses, such as brushing,

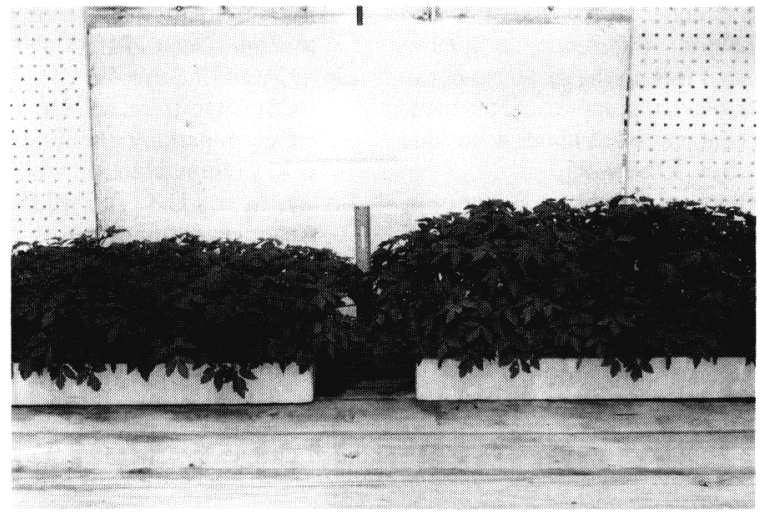

Fig. 2. Twenty-nine-day-old tomato seedlings: (left) after 3 days after 12 nights of being subjected to physical impedance and (right) control.

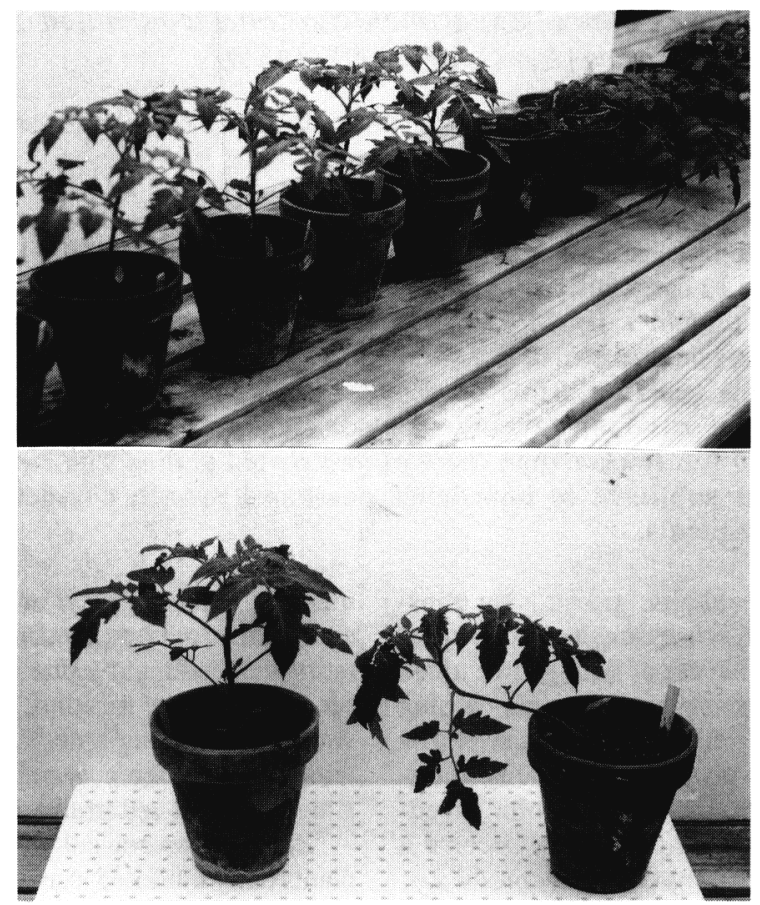

Fig. 3. Physical impedance increased stem resistance to deformation (left), whereas nontreated plants collapsed under their own weight (right). Plants were photographed 12 days after impedance ended.

shaking, and vibration, have decreased stem length and leaf dry weight but also have decreased or not affected the stem diameter of tomato transplants (Heuchert and Mitchell, 1983; Heuchert et al., 1983; Johjima et al., 1992; Liptay, 1985).

Forty-four days after being subjected to impedance, plant stems were shorter (5 1.1 vs. $62.0 \mathrm{~mm} ; P \leq 0.01)$ and thicker (9.2 vs. 10.0 $\mathrm{mm} ; P \leq 0.05)$ than those of the nontreated plants. Treated plants were $21 \%$ and $18 \%$ shorter than control plants 29 and 70 days after seeding, respectively, a result indicating that some of the growth suppression was lost with increasing time after impedance ended. Johjima et al. (1992) found that growth rates ofbrushed tomato transplants equaled those of control plants after impedance ended. No other differences in vegetative characteristics or in fruit production were found between the controls and the treated plants.

Results reported here show that tomato seedlings subjected to physical impedance acquired the desired growth characteristics of plug transplants.

\section{Literature Cited}

Boodley, J.W. and R. Sheldrake, Jr. 1977. Cornel Peat-Lite mixes for commercial plant growing. Cornell Univ. Plant Sci. Info. Bul 43.

Goeschl. J.D.. L. Rappaport, and H.K. Pratt. 1966. Ethylene as a factor regulating the growth of pea epicotyls subjected to physical stress. Plant Physiol. 41:877-884.

Heuchert, J.C., J.S. Marks, and C.A. Mitchell. 1983. Strengthening of tomato shoots by gyratory shaking. J. Amer. Soc. Hort. Sci. 108:801-805.

Heuchert, J.C. and C.A. Mitchell. 1983. Inhibition of shoot growth in greenhouse-grown tomato by periodic gyratory shaking. J. Amer. Soc. Hort. Sci. 108:795-800

Hiraki, Y. and Y. Ota. 1975. The relationship between growth inhibition and ethylene production by mechanical stimulation in Lilium longiflorum. Plant \& Cell Physiol. 16: 185-189. 
Johjima, T., J.G. Latimer, and H. Wakita. 1992. Brushing influences transplant growth and subsequent yield of four cultivars of tomato and their hybrid lines. J. Amer. Soc. Hort. Sci. 117:384-388.

Latimer, J.G. 1991. Mechanical conditioning for control of growth and quality of vegetable transplants. HortScience 26: 1456-1461.
Latimer, J.G. and P.A. Thomas. 1991. Application of brushing for growth control of tomato transplants in a commercial setting. HortTechnology 1:109-110.

Liptay, A. 1985. Reduction of spindliness of tomato transplants growth at high density. Can. J. Plant Sci. 65:797-801.

Mitchell, CA., C.J. Severson, J.A. Wott, and P.A.
Hammer. 1975. Seismomorphogenic regulation of plant growth. J. Amer. Soc. Hort. Sci. 100:161165 .

Samimy, C. 1980. Possible ethylene involvement in differential growth response of hypocotyls of two soybean cultivars to physical impediment. J. Seed Technol. 5:74-81. 